\title{
Impact of the invasive rust Puccinia psidii (myrtle rust) on native Myrtaceae in natural ecosystems in Australia
}

\author{
Angus J. Carnegie $\cdot$ Amrit Kathuria • \\ Geoff S. Pegg • Peter Entwistle • \\ Matthew Nagel $\cdot$ Fiona R. Giblin
}

Received: 5 June 2015/Accepted: 11 October 2015/Published online: 19 October 2015

(C) The Author(s) 2015. This article is published with open access at Springerlink.com

\begin{abstract}
The invasive rust Puccinia psidii (myrtle rust) was detected in Australia in 2010 and is now established along the east coast from southern New South Wales to far north Queensland. Prior to reaching Australia, severe damage from P. psidii was mainly restricted to exotic eucalypt plantations in South America, guava plantations in Brazil, allspice plantations in Jamaica, and exotic Myrtaceous tree species in the USA; the only previous record of widespread damage in native environments is of endangered Eugenia koolauensis in Hawai'i. Using two rainforest tree species as indicators of the impact of $P$. psidii, we report for the first time severe damage to endemic Myrtaceae in native forests in Australia, after only 4 years' exposure to $P$. psidii. A 3-year disease exclusion trial in a natural stand of Rhodamnia
\end{abstract}

Electronic supplementary material The online version of this article (doi:10.1007/s10530-015-0996-y) contains supplementary material, which is available to authorized users.

A. J. Carnegie $(\bowtie) \cdot$ A. Kathuria $\cdot$ M. Nagel

NSW Department of Primary Industries, NSW Forest

Science, Parramatta, NSW, Australia

e-mail: angus.carnegie@dpi.nsw.gov.au

\section{A. J. Carnegie - G. S. Pegg · F. R. Giblin}

Plant Biosecurity Cooperative Research Centre, Bruce,

ACT, Australia

\section{G. S. Pegg}

Department of Agriculture and Fisheries, Horticulture and

Forestry Science, Brisbane, QLD, Australia rubescens unequivocally showed that repeated, severe infection leads to gradual crown loss and ultimately tree mortality; trees were killed in less than 4 years. Significant $(p<0.001)$ correlations were found between both incidence $(\mathrm{r}=0.36)$ and severity ( $\mathrm{r}=0.38$ ) of $P$. psidii and subsequent crown loss (crown transparency). This provided supporting evidence to conclude a causal association between $P$. psidii and crown loss and tree mortality in our field assessments of $R$. rubescens and Rhodomyrtus psidioides across their native range. Assessments revealed high levels of damage by $P$. psidii to immature leaves, shoots and tree crowns-averaging $76 \%$ (R. rubescens) and $95 \%$ (R. psidioides) crown transparencyas well as tree mortality. For $R$. psidioides, we saw exceptionally high levels of tree mortality, with over half the trees surveyed dead and $40 \%$ of stands with greater than $50 \%$ tree mortality, including two stands where all trees were dead. Tree mortality was less prevalent for $R$. rubescens, with only $12 \%$ of trees

\footnotetext{
P. Entwistle

North East Agricultural Services, McLeans Ridge, NSW, Australia

F. R. Giblin

Forest Industries Research Centre, University of the Sunshine Coast, Maroochydore, QLD, Australia
} 
surveyed dead and two sites with greater than $50 \%$ mortality. Any alternative causal agents for this tree mortality have been discounted. The ecological implications of this are unclear, but our work clearly illustrates the potential for $P$. psidii to negatively affect Australia's biodiversity.

Keywords Invasive fungi - Guava rust - Eucalyptus rust · Biodiversity · Environmental monitoring · Ecological impacts $\cdot$ Extinction risk $\cdot$ Environmental change

\section{Introduction}

Puccinia psidii Winter is an invasive pathogen of global significance that has rapidly expanded its international range over the past decade. It infects and kills newly expanding leaves and stems, as well as fruit and flowers (Ferreira 1983; Coutinho et al. 1998), and has a wide host range within Myrtaceae (Carnegie and Lidbetter 2012; Giblin and Carnegie 2014). Described from common guava (Psidium guajava) in Brazil (Winter 1884), and believed to be native to South and Central America, it gained notoriety in its country of origin in the 1970s following severe damage in nurseries and plantations of exotic Eucalyptus species (Ferreira 1983). Puccinia psidii has also significantly affected guava production in Brazil (Ferrari et al. 1997; Lim and Manicom 2003). While not known to cause severe damage in undisturbed natural environments in Brazil, probably due to coevolution of hosts and pathogen, the invasive potential of $P$. psidii was realized when it established on new continents. Although known for many years in Jamaica on exotic Syzygium jambos (Dale 1955), a new strain detected in 1934 caused extensive damage to Pimento dioica (allspice) plantations, resulting in the collapse of the allspice industry in certain regions within two years (MacLachlan 1938). In Florida, USA, $P$. psidii was first identified on $P$. dioica in 1977 (Marlatt and Kimbrough 1980), but it was not until new strains invaded that severe epiphytotics occurred; firstly on Melaleuca quinquenervia in the late 1990s (Rayachhetry et al. 1997) and more recently on Rhodomyrtus tomentosa (Rayamajhi et al. 2013) both exotic invasive weeds in Florida. When $P$. psidii reached Hawai' $i$ in 2005 (Uchida et al. 2006), it spread quickly and within several years was causing extensive damage to exotic S. jambos (Uchida and Loope 2009) and threatening native endangered Myrtaceae (Loope 2010). In the past decade, P. psidii has also invaded Japan (Kawanishi et al. 2009), China (Zhuang and Wei 2011), Australia (Carnegie et al. 2010), South Africa (Roux et al. 2013) and New Caledonia (Giblin 2013). The disease it causes is variably known as guava rust, eucalyptus rust or myrtle rust.

Prior to reaching Australia, the known host range for $P$. psidii was 129 species in 33 genera of Myrtaceae, including important Australian genera such as Eucalyptus, Melaleuca and Leptospermum (Carnegie and Lidbetter 2012). Australia is floristically dominated by Myrtaceae, which is widespread and abundant across the continent and thus important in many ecological processes (Myerscough 1998). Many industries are reliant on Myrtaceae, including forestry, nursery, essential oils and cut flower, and the conservation and biodiversity reliance on Myrtaceae cannot be overstated. As such, P. psidii had been recognized as a serious biosecurity threat in Australia for some time (Commonwealth Department of Primary Industry 1985; Grgurinovic et al. 2006; Glen et al. 2007). In April 2010, P. psidii was detected in New South Wales (NSW), Australia; an eradication attempt ensued, but ultimately failed (Carnegie et al. 2010; Carnegie and Cooper 2011). Once established outside of nurseries, it spread rapidly, becoming established in the natural ecosystem throughout coastal NSW and south-east Queensland by mid2011 and in far north Queensland by mid-2012 (Carnegie and Lidbetter 2012; Pegg et al. 2014). Puccinia psidii has now established, albeit with limited distribution, in Victoria (http://agriculture. vic.gov.au), Tasmania (http://dpipwe.tas.gov.au) and the Northern Territory (http://www.nt.gov.au/). A large number of naïve hosts have thus been exposed to this pathogen and as a result the host range has rapidly expanded. There are now 232 species known as hosts due to natural infection in Australia (all but 18 native to Australia) and another 115 hosts recorded from artificial inoculation only, bringing the total hosts for $P$. psidii globally to over 450 species and 73 genera (Carnegie and Lidbetter 2012; Morin et al. 2012; Pegg et al. 2014; Giblin and Carnegie 2014).

The perceived threat to Australian biodiversity and industry is now being realized. Severe damage to key species has been observed in native environments, 
including rainforest understorey species such as Rhodamnia rubescens and Rhodomyrtus psidioides and the keystone wetland species M. quinquenervia (Carnegie and Cooper 2011; Carnegie and Lidbetter 2012; Pegg et al. 2014). The essential oil industry is being significantly affected, particularly lemon myrtle (Backhousia citriodora), and although P. psidii has been found in eucalypt plantations, the forest industry has not yet been severely affected (Carnegie 2015). Puccinia psidii has been listed as a key threatening process to the natural environment in NSW (http:// www.environment.nsw.gov.au/determinations/exoti crustfungiFD.htm), and was recently nominated (unsuccessfully) as a key threatening process at the federal level (Makinson 2014). However, limited studies on the effects of $P$. psidii in the native environment have been initiated. This is surprising considering the heightened publicity $P$. psidii received prior to introduction and during the emergency response, and the anticipated threat to native Myrtaceae and biodiversity. Thus our objective was to gather critical data on the potential threat of $P$. psidii in natural ecosystems in eastern Australia using two rainforest species- $R$. rubescens and $R$. psidioides - as indicators of the impact of $P$. psidii. We conducted a manipulative field experiment (disease exclusion trial) in a natural stand of $R$. rubescens over 3 years to gather rigorous quantitative data on the progression of disease and its subsequent effects on crown health and tree survival. Extensive field assessments of $P$. psidii damage and tree health were conducted across the native range of our two indicator species to obtain an understanding of the extent and severity of the impact of $P$. psidii in natural ecosystems in Australia.

\section{Methods}

Selected study species

We selected two rainforest species to quantify the impact of $P$. psidii in natural ecosystems in Australia and to illustrate the potential for $P$. psidii to affect similarly susceptible Myrtaceae. The two species, $R$. rubescens and $R$. psidioides, are listed as highly to extremely susceptible to $P$. psidii, including fruit infection, based on field observations in Australia (Carnegie and Cooper 2011; Carnegie and Lidbetter 2012; Pegg et al. 2014). Rhodamnia rubescens (brush turpentine) is a common pioneer species in subtropical, cool and warm temperate rainforests, with a coastal distribution from Batemans Bay in southern NSW to Gympie in southern Queensland (Floyd 1989) (Fig. 1). It is an understorey shrub to small tree with dense foliage, and although reported to reach heights of $25 \mathrm{~m}$ (Floyd 1989), we rarely observed trees over $15 \mathrm{~m}$. Rhodomyrtus psidioides (native guava) is an understorey shrub to small tree (to $12 \mathrm{~m}$ ) found in littoral rainforests and wet sclerophyll forests with a coastal distribution from Gosford on the Central Coast of NSW to Gympie in southern Queensland (Floyd 1989) (Fig. 2). It is known as a pioneer species in disturbed environments (Williams and Adam 2010). Puccinia psidii is known to have been established across the range of these species since mid-2011 (www.bionet.nsw.gov.au/; Carnegie and Lidbetter 2012; Pegg et al. 2014). There is a paucity of botanical or ecological research on these two species: both are known to be susceptible to drought and frost, but have few natural enemies, and are often described as good "screen" trees for their dense foliage (Floyd 1989; Shaw 2015; www.noosanativeplants.com.au). Neither species was considered as either rare or of conservation concern prior to 2010 and are still currently listed as 'Least Concern' under state and federal legislation (http://www.environment.nsw.gov.au/threatenedspeci es/; http://www.ehp.qld.gov.au/wildlife/threatened-spec ies/; http://www.environment.gov.au/biodiversity/threat ened/species).

Effect of repeated damage by Puccinia psidii on Rhodamnia rubescens: Olney State Forest disease exclusion trial

\section{Trial design}

A disease exclusion trial was established in Olney State Forest (SF) $\left(33^{\circ} 07^{\prime} 53^{\prime \prime} \mathrm{S}, 151^{\circ} 15^{\prime \prime} 30^{\prime \prime} \mathrm{E}\right)$ on the Central Coast of NSW to quantify the effect of repeated damage from $P$. psidii on $R$. rubescens and examine the progress of disease symptoms over time. The site selected was a wet sclerophyll forest in a moist gully with an abundance of $R$. rubescens ranging in size from newly emerging seedlings to $12+\mathrm{m}$ trees. Overstorey trees included Syncarpia glomulifera and Eucalyptus spp., with the understorey dominated by $R$. rubescens and Allocasuarina sp. Puccinia psidii was first detected in Olney SF in October 2010 


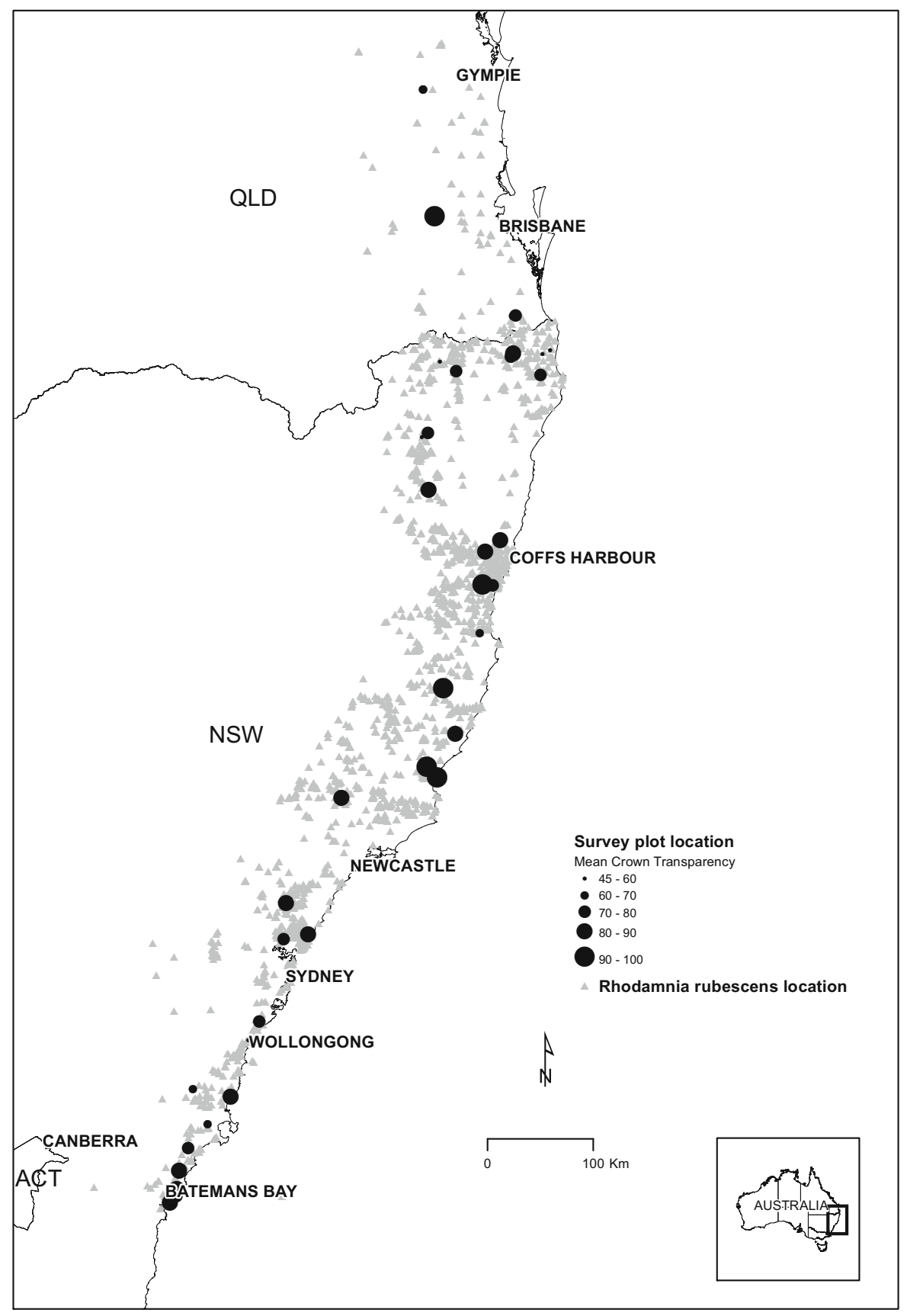

Fig. 1 Map of Rhodamnia rubescens survey sites. Native distribution of R. rubescens (grey triangles) obtained from Atlas of Living Australia (www.ala.org.au) and mean crown transparency of survey plots (graduated circles)

(Carnegie and Cooper 2011), 6 months after P. psidii was detected in Australia; Olney SF is less than $10 \mathrm{~km}$ north of the first known infected location in Australia. It is likely that $P$. psidii had been present for several months prior to being detected.
Twenty trees were selected by walking a linetransect through the forest and every $5 \mathrm{~m}$ selecting the nearest $R$. rubescens tree $\sim 0.5$ to $\sim 4.0 \mathrm{~m}$ in height (trees above this height would be too difficult to spray). Ten trees were then randomly assigned as 


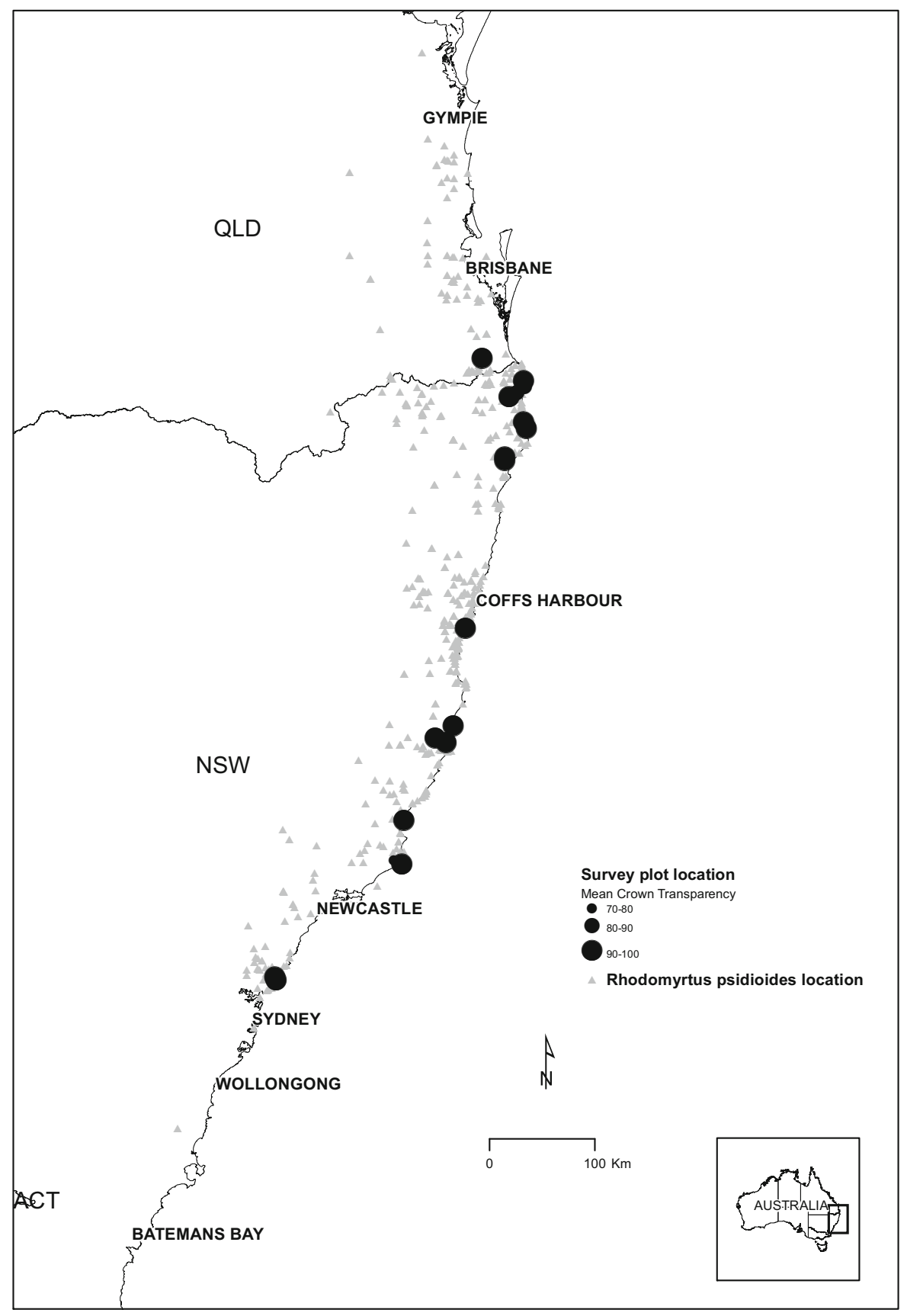

Fig. 2 Map of Rhodomyrtus psidioides survey sites. Native distribution of R. psidioides (grey triangles) obtained from Atlas of Living Australia (www.ala.org.au), and mean crown transparency of survey plots (graduated circles)

treated (sprayed) and 10 as untreated (not sprayed). All foliage on treated trees was sprayed to run-off with the fungicide triadimenol $(50 \mathrm{~mL} / 100 \mathrm{~L})$ - which is registered in Australia for control of P. psidii (http:// permits.apvma.gov.au/PER12319.PDF)—with a manual pressurized back-pack spray unit. Fungicide application generally occurred monthly from August 2011 to October 2014. From June 2013, the ten treated trees were split into two groups with five individuals randomly selected for ongoing fungicide treatment while the other five were no 
longer treated with fungicide (hereafter termed "partially treated"). This was carried out so that trees could recover from infection for a period, so that we could then follow disease progression from initial infection onwards, similar to original disease establishment in the forest.

\section{Tree assessments}

The whole crown of each tree was assessed for crown transparency (Schomaker et al. 2007) monthly from August 2011 to October 2014 to provide an indication of the impact on tree health due to repeated damage from P. psidii: low transparency (e.g. $25 \%$ ) indicated many leaves in the crown and limited impact from $P$. psidii infection; high transparency (e.g. $75 \%$ ) indicated few leaves and a high level of impact. No other causal agent of defoliation (e.g. herbivores or drought) was observed during the course of the study. Incidence and severity of $P$. psidii was assessed on leaves to gain an understanding of the relationship between leaf damage and crown transparency and to follow progression of damage over time. Incidence (\% infected) and severity (\% leaf area affected on diseased leaves) of $P$. psidii was assessed on leaves on individual branches from August 2011 to December 2012 and thereafter on leaves in the whole crown up to October 2014 as follows. Three branches per tree were randomly selected and tagged $30 \mathrm{~cm}$ from the tip and each month from August 2011 to December 2012 the number of leaves (immature and mature leaves combined) on each branch counted and the incidence and severity of $P$. psidii on these leaves assessed. "Immature" leaves had recently been produced and were still susceptible; "mature" leaves, representing several leaf cohorts, had previously been susceptible, but had since matured and were no longer susceptible to new infection. From March 2013 to October 2014, individual branches were no longer assessed and the incidence and severity of $P$. psidii on the immature leaves only, across the whole crown, was assessed at monthly intervals. The methodology was modified as many of the tagged branches on the untreated trees had died by March 2013, hence further data was collected by assessing $P$. psidii in the whole crown. Only these later assessments (March 2013-October 2014) were used to conduct comparative analysis with crown transparency and leaf flush. An estimate of the proportion of immature leaves in the whole crown, providing an indication of leaf flush events, was also assessed monthly from March 2013 to October 2014. Development of flowers and fruit, and incidence of rust on each, was to be assessed, however neither flower nor fruit production was observed during this study.

\section{Quantification of infected leaf area and leaf size on Rhodamnia rubescens at Olney SF}

Within 6 months of initiation of the Olney SF disease exclusion trial we observed a difference in disease severity and an apparent difference in the size of newly developed (immature) leaves between treated and untreated trees. We hypothesized that this difference in leaf size was due to repeated severe leaf damage and subsequent defoliation on untreated trees resulting in reduced carbon assimilation, thus affecting ongoing leaf development. To further examine this, leaves were collected and the leaf area damaged by $P$. psidii (severity) and the total leaf area (size) of both treated and untreated trees were assessed. Three branches per tree from each of the 20 trees were randomly selected (but avoiding tagged branches above) and two leaves per leaf category (old, mature and immature) were sampled six months after treatment began (i.e. 2 leaves $\times 3$ leaf categories $\times 3$ branches $=18$ leaves $/$ tree). For this experiment we designated three categories of leaf age to try to differentiate the effect of treatment on leaf production (=leaf size): "old" leaves had matured prior to commencement of the trial and so any rust on these was from previous episodes of infection; "mature" leaves, representing several leaf cohorts, would have been produced after the trial commenced and so would have been susceptible, but had matured and were no longer susceptible at the time they were sampled; "immature" leaves had recently emerged and were susceptible. Whole leaves were removed, placed in paper bags, pressed in a herbarium press while still fresh and scanned using an HP Color LaserJet CM3530fs MFP. The image processing software QUANT (Vale et al. 2003) was used to quantify leaf area $\left(\mathrm{mm}^{2}\right)$ and the percentage of leaf area damaged by $P$. psidii ( $P$. psidii severity).

The impact of Puccinia psidii on indicator species across their native range

To gain an understanding of the impact of $P$. psidii on our indicator species, and ascertain whether there was 
any variation in susceptibility, we assessed native stands of each species across the range of their natural distribution. Stands were selected via feedback of local ecologists (e.g. Forestry Corporation of NSW; National Parks and Wildlife Service) and from species location data obtained from the Atlas of Living Australia (www.ala.org.au/). While some stands were already known to have a history of $P$. psidii related dieback, such as those listed in the Atlas of NSW Wildlife (www.bionet.nsw.gov.au/), many sites were selected without any prior knowledge of $P$. psidii presence to remove bias from site selection. Stands were selected if they were in native forests and ideally contained at least 20 individuals. At each site (GPS coordinates obtained), a central point was located within the stand and the nearest 20 individuals marked for assessment. Individuals smaller than $\sim 0.5 \mathrm{~m}$ in height were not included.

For each tree, assessments were made of $P$. psidii infection and damage: (1) crown transparency (Schomaker et al. 2007), (2) incidence of $P$. psidii (\% infected) on (a) immature leaves, (b) mature leaves and (c) flowers and fruits (if present), and (3) a disease rating score (Pegg et al. 2012). Dead trees were classed as $100 \%$ crown transparency; results from the Olney SF exclusion trial, and our extensive field observations, indicated that such trees might produce epicormic growth or re-shoot, but that this foliage subsequently became infected and died. No other causal agent of defoliation (e.g. herbivores or drought) was observed during our assessments. For disease incidence assessments, immature leaves were those that had not fully expanded and were thus still susceptible to $P$. psidii; mature leaves were no longer susceptible, but may have previously been infected when immature and were still retained on trees. Disease rating ( $0-4$ scale) was based on the scale developed by Pegg et al. (2012), where $0=$ no evidence of $P$. psidii symptoms, up to $4=$ rust pustules present on the majority of immature leaves and shoots and evidence of stem and shoot dieback. Based on results from the Olney SF disease exclusion trial, a posteriori knowledge of our indicator species, and typical foliage and stem and branch dieback symptoms associated with repeated infection (Pegg et al. 2014), we were confident that damage and crown loss observed at sites assessed was caused by $P$. psidii. Both our indicator species are evergreen.
Binoculars were used to assess tall trees where necessary. Tree height $(\mathrm{m})$ was measured with either a height pole or laser rangefinder/height meter. Sites were assessed between January and October 2014, roughly 3-3.5 years after $P$. psidii had established in natural ecosystems across the natural range of these two species.

At each site we examined trees for typical symptoms of $P$. psidii infection and damage (Carnegie and Lidbetter 2012; Pegg et al. 2014) to confirm presence of the disease. This included yellow sori on immature leaves and stems, old grey sori on mature leaves which had been infected when immature, and branch and stem dieback. No other disease established in Australia presents similar symptoms (Walker 1983). At a selection of sites, samples were collected for further examination in the laboratory and molecular confirmation of $P$. psidii (results presented in Pegg et al. 2014; Machado et al. 2015).

\section{Statistical analyses}

Effect of repeated damage by Puccinia psidii

on Rhodamnia rubescens: Olney State Forest disease exclusion trial

Crown transparency data were measured at regular intervals so the data are a time series and the observations over time on the same experimental unit (tree) cannot be assumed to be independent. A mixed effect model was used to model the auto-correlation structure. An auto-correlation between the residuals of different time points was modeled by introducing a stationary auto-correlation function of order 1 (Chatfield 2003; Diggle 1990). This error structure models the residuals at time $t\left(u_{t}\right)$ as a function of residuals at time $\mathrm{t}-1\left(\mathrm{u}_{\mathrm{t}-1}\right)$ along with the noise $\left(\varepsilon_{\mathrm{t}}\right)$ :

$u_{t}=\rho u_{t-1}+\varepsilon_{t}$

The parameter $\rho$ is unknown, and needs to be estimated from the data. This error structure results in the following correlation structure:

$\operatorname{cor}\left(u_{t}, u_{s}\right)= \begin{cases}1 & \text { if } t=s \\ \rho^{|s-t|} & \text { else }\end{cases}$

Treatment and time were used as fixed effects. Initial plotting indicated a non-linear trend with time, so a smoothing spline was fitted with time. The fitted model is: 


$$
\begin{aligned}
\text { Response variable }= & \text { intercept }+ \text { Treatment } \\
& +f_{1}(\text { time }): \text { Treatment }+\varepsilon
\end{aligned}
$$

where crown transparency is the response variable, treatment (=treated, untreated and partially treated), and time is the number of days since the start of the study period. A separate spline function $\left(f_{1}\right)$ is fitted for each treatment over time rather than assuming a linear relationship.

Maximum likelihood was used when comparing nested models where the fixed effects differed (Zuur et al. 2009). Likelihood ratio tests and t statistics were used to identify the significant fixed effect terms in the model. Model was validated by inspecting the residual plots to check for homogeneity, independence and normality.

\section{Quantification of infected leaf area and leaf size at Olney SF}

Observations were made within trees for the leaf area data, so the observations are not independent and hence a mixed effects model was fitted to the data. Fixed effects that were included in the model were treatment, crown transparency and leaf class (old, mature, immature). Crown transparency was included in the model as we had hypothesized that high crown transparency would result in a reduction in photosynthetic area and thus a reduction in size of newly produced leaves due to depletion of reserves. For the analysis, we included crown transparency assessment dates that we believed would have had some effect on foliage production for each leaf class (i.e. crown transparency prior to or at the time of foliage production): for immature leaves, we used mean crown transparency from the two preceding assessments (February 2012 and December 2011); for mature leaves we used mean crown transparency for the December 2011 and November 2011 assessments (these leaves had matured by the February 2012 assessment); for old leaves we used crown transparency from August 2011 only.

The full model fitted is:

$$
\begin{aligned}
\text { Response variable }= & \text { intercept }+ \text { Treat }+L C \\
& + \text { Trans }+ \text { Treat }: L C+\alpha+\varepsilon
\end{aligned}
$$

where response variable is the leaf area or the severity of P. psidii on leaves (P. psidii severity), Treat, LC, Trans, Treat:LC, are the terms for fixed effects for treatment, leaf class, crown transparency and the interaction of treatment and leaf class, and $\alpha, \varepsilon$ are the random effects for the tree and the error terms. The variances for the treated and the untreated for severity data were different. The heteroscedasticity structure was specified by weights argument in the model. The model was fitted using likelihood ratio tests for significance testing.

\section{The impact of Puccinia psidii on indicator species across their native range}

The crown transparency data has an inherent nested structure as the trees are nested within locations and cannot be assumed to be independent as is required for linear regression. The data were therefore analyzed using mixed models (Pinheiro and Bates 2000). Restricted maximum likelihood (Zuur et al. 2009) was used to compare nested models in which only the random effects differed. Following the final random effect structure the model was tested for fixed effects. Likelihood ratio tests and $\mathrm{t}$ statistics were used to identify the significant fixed effect terms in the model.

Previous rust (site with a known history of $P$. psidii), disease rating, disease incidence on immature leaves, disease incidence on mature leaves, and height were used as the fixed variables. Location was used as the random variable. The full model that was fitted was:

$$
\begin{aligned}
\text { Response variable }= & \text { intercept }+D R+P R+M L \\
& +H t+I L+\alpha+\varepsilon
\end{aligned}
$$

where crown transparency is the response variable, DR, PR, ML, IL, Ht, are the fixed effect terms for disease rating, previous rust, disease incidence on mature leaves, disease incidence on immature leaves and height, and $\alpha, \varepsilon$ are the random effects for the location and the error terms. We included previous rust in the analysis to determine whether there was any bias in our selection of sites we already knew had disease compared to those with an unknown disease history.

We also tested whether region-using Köppen climate classification and seasonal rainfall data (www. bom.gov.au) — had an effect on disease of $R$. rubescens and $R$. psidioides across the survey sites. However, there was no effect so we did not report on this 
further. Pearson correlation coefficient was calculated between crown transparency, severity on immature and mature leaves and disease scores.

All analyses were conducted using R (R Core Team 2014), nlme (Pinheiro et al. 2014) and plotting was done using ggplot2 (Wickham 2009) and lattice (Sarkar 2008).

\section{Results}

Effect of repeated damage by Puccinia psidii on Rhodamnia rubescens: Olney State Forest disease exclusion trial

Monthly application of the fungicide triadimenol was effective in controlling $P$. psidii on $R$. rubescens in the native environment (Figs. 3, 4, Supplementary Fig. 1). If fungicide application extended beyond this time-frame, control was not effective (Supplementary Fig. 1, arrows). Active P. psidii infection (sori producing yellow urediniospores) was observed at every assessment date on untreated trees. There was a significant difference $(p<0.001)$ in crown transparency between treated, untreated and partially treated trees (Fig. 3). There was a significant autocorrelation $(\rho)$ between values over time for each tree $(\rho=0.2, p=0.01)$. The smoother terms were all significant $(p<0.001)$ and had 5, 3 and 5 degrees freedom for untreated, treated and partially treated trees, respectively, indicating that the trends in crown transparency over time are non-linear. Based on data from March 2013 to October 2014, crown transparency was moderately correlated with incidence $(\mathrm{r}=0.36, \quad p<0.001)$ and severity $(\mathrm{r}=0.38$, $p<0.001)$ of disease on immature leaves and with percentage new flush $(\mathrm{r}=0.51, p<0.001)$; incidence and severity were highly correlated $(\mathrm{r}=0.86$, $p<0.001$ ); and percentage new flush was moderately correlated with incidence $(\mathrm{r}=0.34, p<0.001)$ and severity $(r=0.31, p<0.001)$ of disease on immature leaves.

This trial allowed observations of disease progression, and the subsequent impact of this on trees, over time. At the beginning of the trial, all trees had similar crown transparency (Fig. 3) as well as incidence and severity on mature and immature leaves (data not shown). As the trial progressed, incidence and severity of $P$. psidii infection on treated trees effectively became zero while disease on untreated trees fluctuated, but was significantly greater than on treated trees (Supplementary Fig. 1). This corresponded with an increase in crown transparency on untreated trees and a decrease on treated trees (Fig. 3). Significant periods of leaf production (leaf flush) generally followed a trend of increasing during warm wet periods of the
Fig. 3 Time series plot of mean crown transparency of all Rhodamnia rubescens trees for the disease exclusion trial at Olney State Forest. The lines are locally weighted scatterplot smoothing curves (loess) and the shaded areas are the $95 \%$ confidence interval. Red untreated, Blue treated, Green partially treated (treatment ceased in June 2013)

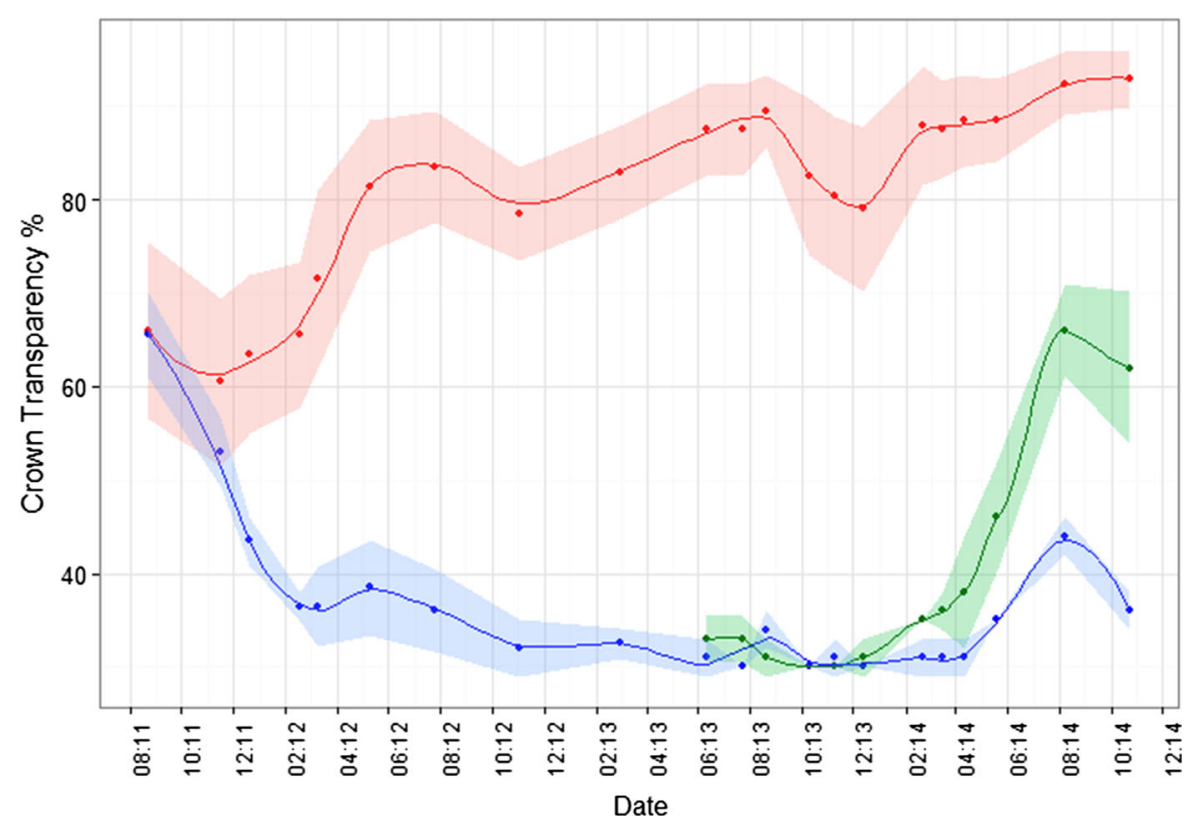




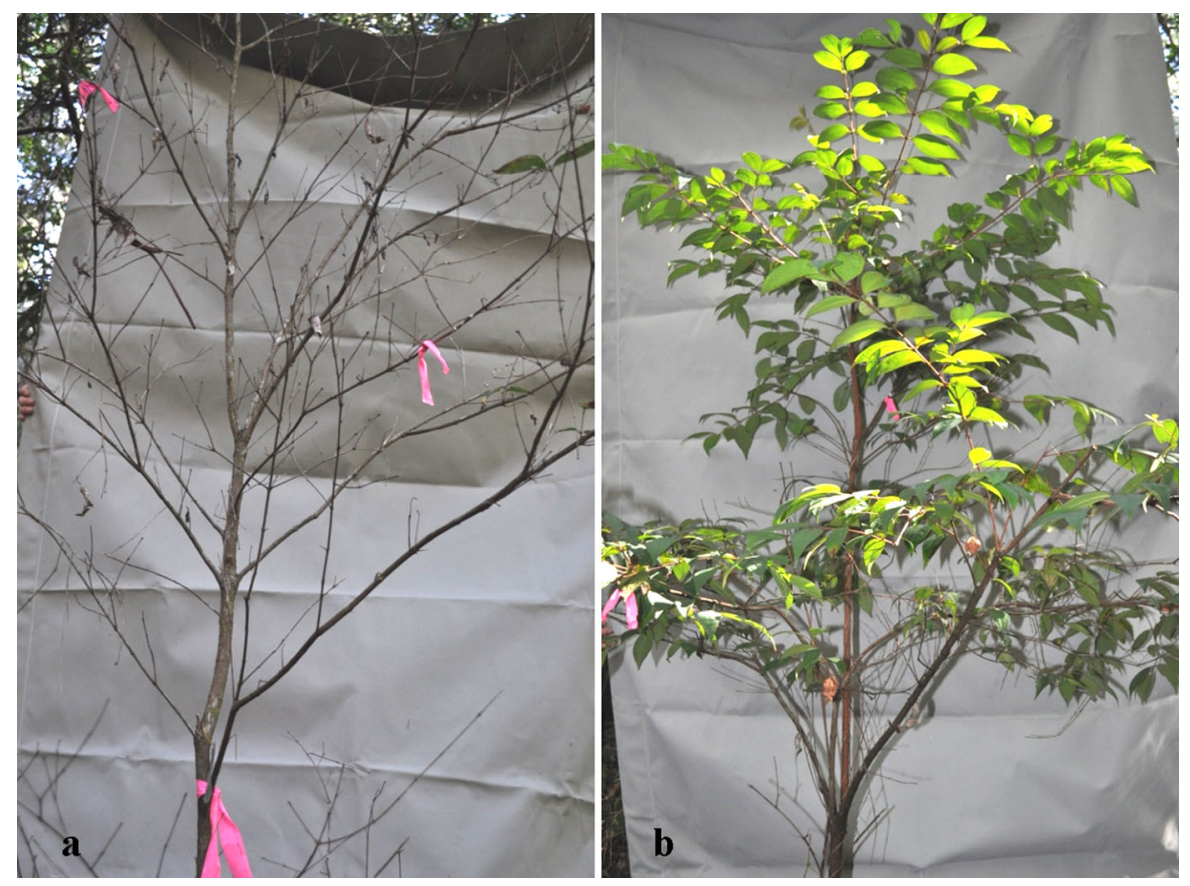

Fig. 4 Comparison of untreated tree (a) and treated tree (b) of Rhodamnia rubescens in the disease exclusion trial at Olney State Forest 24 months after commencement of the trial and approx. 3 years after Puccinia psidii established in the forest

year (i.e. spring to summer), but this was not always consistent (Supplementary Fig. 1). Untreated trees had a greater proportion of the crown as new flush, compared to treated trees, as the majority of matured leaves had fallen on untreated trees. Incidence and severity of $P$. psidii generally followed a trend of increasing during periods of high rainfall and reducing during dry periods over winter (Supplementary Fig. 1), but again this was not always consistent. A similar trend, with a slight time lag, was observed for crown transparency (Fig. 3). Generally, peaks in incidence and severity occurred a month or so following peaks in leaf flush (Supplementary Fig. 1). A more detailed epidemiological study will be carried out on this data.

Time-series observations of untreated trees revealed that immature leaves became infected and often distorted and died. This resulted in a proliferation of new shoots and immature leaves that subsequently became infected and distorted with many dying. Within 6 months of the trial commencing, any new (immature) leaves on untreated trees were noticeably smaller than those on treated trees. Over time, mature leaves that had been retained on untreated trees prior to the trial beginning were shed, with little replacement (thus increasing crown transparency). Occasionally, a new flush of leaves did not coincide with conditions optimal for disease, resulting in little infection and a cohort of leaves surviving to maturity (and a subsequent decrease in crown transparency). In contrast, on treated trees, immature leaves were able to fully expand and were retained on trees, thus resulting in a decrease in crown transparency.

When we divided the treated trees into two groups in June 2013, we saw no noticeable change in disease incidence and severity or crown transparency in the now untreated (partially treated) trees for 6 months, then a sharp increase in incidence and severity in early 2014 (Supplementary Fig. 1) followed by an increase in crown transparency (Fig. 3), significantly different $(p<0.001)$ from the treated trees.

In December 2013 we began to observe some untreated trees almost completely defoliated and with any retained immature leaves distorted and dead (Fig. 4a). These trees subsequently produced a small amount of new flush, which was again severely infected, and by August 2014 these trees ceased to produce new flush and had died. A separate assessment of 100 trees in this stand (see section below "The impact of Puccinia psidii on selected species across 
their native range"), revealed that $53 \%$ of trees had died by October 2014. Thus, tree mortality had occurred in this native ecosystem less than four years after $P$. psidii had established in this forest.

\section{Quantification of infected leaf area and leaf size}

Severity of $P$. psidii on leaves collected from the disease exclusion trial at Olney SF was significantly $(p<0.001)$ higher on the untreated compared to the treated trees for all three leaf classes, but more so for the mature and immature leaves. The size of leaves (leaf area) was not significantly different between treated and untreated trees for the old and mature leaf class, but was significantly different between treatments for the immature leaf class $(p=0.004)$. Mean and standard errors (SE) for severity of $P$. psidii and leaf area are presented in Table 1. Immature leaves assessed using QUANT were produced generally 4-5 months after initiation of the trial, and so we expected some influence of reducing crown transparency of untreated trees on leaf production. However, previous crown transparency on trees from which leaves were collected was not a significant factor in determining leaf area or disease severity.

The impact of Puccinia psidii on indicator species across their native range

For $R$. rubescens, we assessed 43 sites across the native range from Murramarang National Park $\left(35^{\circ} 40^{\prime} 45^{\prime \prime} \mathrm{S}, 150^{\circ} 16^{\prime} 55^{\prime \prime} \mathrm{E}\right)$ near Batemans Bay, NSW, to Traveston Crossing $\left(26^{\circ} 11^{\prime} 43^{\prime \prime} \mathrm{S}\right.$, $152^{\circ} 25^{\prime} 30^{\prime \prime} \mathrm{E}$ ) near Gympie, Queensland (Fig. 1), with $P$. psidii present at all sites. The mean crown transparency was $76.29 \%$ (SE $0.81 \%$ ), with the majority $(79 \%)$ of trees having greater than $60 \%$ transparency (Fig. 5a). Based on the disease exclusion trial, and a posteriori knowledge of the species, we surmise the normal crown transparency of $R$. rubescens in an understorey is approx. 30-35\%. We observed tree mortality at 18 sites, mostly only a few trees, but five sites with between 20 and $40 \%$ of trees dead, one site with half the trees dead and another with three-quarters of the trees dead (Table 2). Overall, $12 \%$ of trees surveyed were classed as dead (Fig. 5a). There was no evidence of any other primary causal agent that could have been responsible for this tree mortality. Mean disease incidence was greater on immature leaves [56.37\% (SE 2.08\%)] than on mature leaves [29.76\% (SE $1.16 \%$ )], with a mean disease rating (score) of 2.40 (SE 0.08). Crown transparency was significantly $(p<0.001)$ negatively correlated with tree height, and positively correlated with disease rating and incidence of disease on mature leaves (Table 3), but not with incidence of disease on immature leaves or previous presence of rust at the location. The disease rating score was highly correlated with incidence on immature leaves $(r=0.89$, $p<0.001)$.

For $R$. psidioides, we assessed 18 sites from Wambina Nature Reserve ( $\left.33^{\circ} 24^{\prime} 60^{\prime \prime} \mathrm{S}, 151^{\circ} 20^{\prime} 34^{\prime \prime} \mathrm{E}\right)$ near Gosford, NSW, to Tallebudgera Valley $\left(28^{\circ} 7^{\prime} 15^{\prime \prime} \mathrm{S}, 153^{\circ} 12^{\prime} 48^{\prime \prime} \mathrm{E}\right)$ near Beechmont, Queensland (Fig. 2), with $P$. psidii present at all sites. The mean crown transparency was $94.88 \%$ (SE $0.53 \%$ ), with the majority of trees (82\%) having greater than $90 \%$ transparency (Fig. 5b). Based on a posteriori knowledge of the species, we surmise the normal crown transparency of $R$. psidioides in an understorey

Table 1 Mean and standard error (SE) of percentage severity of Puccinia psidii and leaf area of old, mature and immature leaves from treated and untreated trees analyzed with the image processing software QUANT from the Olney SF disease exclusion trial

\begin{tabular}{|c|c|c|c|c|c|}
\hline \multirow[t]{2}{*}{ Treatment } & \multirow[t]{2}{*}{ Leaf class } & \multicolumn{2}{|c|}{ P. psidii severity $(\%)$} & \multicolumn{2}{|c|}{ Leaf area $\left(\mathrm{mm}^{2}\right)$} \\
\hline & & Mean & SE & Mean & SE \\
\hline 0 & Old & 16.81 & 3.70 & 71.32 & 8.51 \\
\hline 1 & Old & 6.40 & 0.78 & 68.83 & 8.27 \\
\hline 0 & Mature & 11.06 & 2.54 & 58.03 & 11.43 \\
\hline 1 & Mature & 0.36 & 0.08 & 69.12 & 8.50 \\
\hline 0 & Immature & 19.13 & 5.81 & 14.03 & 3.21 \\
\hline 1 & Immature & 0.97 & 0.50 & 49.44 & 5.61 \\
\hline
\end{tabular}

$0=$ untreated; $1=$ treated 
Fig. 5 Total tree counts (across all sites) for crown transparency (grey bars) in $10 \%$ classes-and tree mortality (black bar) associated with Puccinia psidii for a Rhodamnia rubescens and

b Rhodomyrtus psidioides from field assessments across the species' native ranges

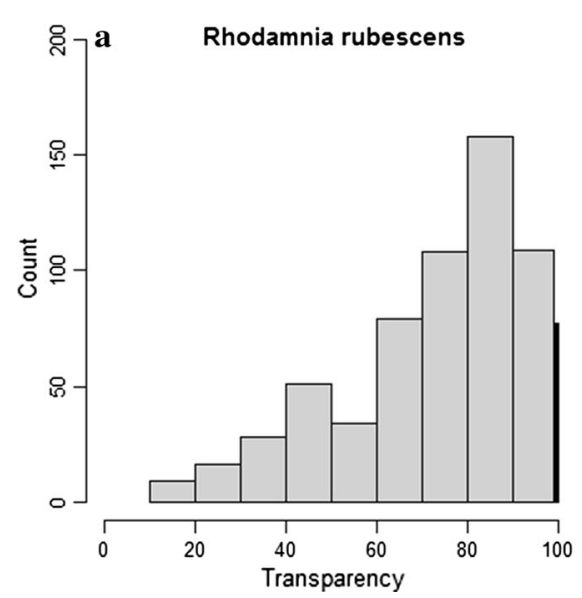

is approx. $25-35 \%$. All but 3 sites had exceptional levels of tree mortality (Table 4), with four sites having 50-75\% dead trees, two sites with $95 \%$ dead trees, and two sites with all trees $(100 \%)$ dead. Overall, $57 \%$ of trees surveyed were dead (Fig. 5b). Trees of all sizes were killed, including trees as tall as $12 \mathrm{~m}$ in height (Fig. 6), with the stage of decline indicating some had been dead for at least 1 year (i.e. 2 years after $P$. psidii established in the region). There was no evidence of any other primary causal agent that could have been responsible for this tree mortality. Mean disease incidence was greater on immature leaves [94.46\% (SE 2.12\%)] than on mature leaves [38.44\% (SE $3.18 \%)$ ], with a mean disease rating (score) of 3.87 (SE 0.05). Crown transparency was not significantly correlated with any other variable assessed (data not shown).

For both these species, we observed severely damaged trees with epicormic shoots infected and killed by $P$. psidii. Ad hoc observations during surveys revealed few regenerating seedlings and/or suckers, and all with $P$. psidii infection and associated dieback.

\section{Discussion}

The disease exclusion trial at Olney SF unequivocally showed that repeated, severe infection by $P$. psidii results in a reduction in foliage production, severely affects crown health and can lead to tree death. It also revealed that myrtle rust is capable of killing mature trees in a native forest ecosystem in fewer than four years. This trial provided strong supporting evidence for our conclusions that the severe crown loss, dieback and tree mortality we observed in $R$. rubescens and $R$. psidioides across their native range was a result of repeated infection by $P$. psidii. Any alternative causal agents have been discounted. This is supported by previous studies (Pegg et al. 2014; Shaw 2015).

Puccinia psidii has caused significant damage in commercial plantations and orchards in South and Central America (to both exotic and endemic species), to invasive weed species in Florida and Hawai'i, and to endangered endemic species in Hawai'i. This disease is now causing significant damage to endemic Myrtaceae in natural ecosystems in Australia. Severe infection and crown loss, dieback and tree mortality were observed in our indicator species- $R$. rubescens and $R$. psidioides - across their entire native range. Rhodomyrtus psidioides has been particularly affected, with deaths of over half the trees in many stands within 2-3 years of $P$. psidii establishing, including mature trees up to $12 \mathrm{~m}$ tall. This species is now undergoing a process of rapid decline across its range as a result of $P$. psidii invasion: of the 297 trees across 18 stands that we assessed, $57 \%$ are dead, with all but three sites having exceptional levels of tree mortality. We know from observations of botanists and seed collectors that stands of $R$. psidioides were healthy prior to $P$. psidii establishing (Shaw 2015). Thus, based on our data, $R$. psidioides has undergone a population decline of greater than $50 \%$ in less than five years. Similar impact has been observed in Hawai' $\mathrm{i}$ to endangered Eugenia koolauensis and mature trees of the exotic S. jambos (Uchida and Loope 2009; Loope 2010), but not previously to an 
Table 2 Percentage of Rhodamnia rubescens trees assessed as dead at each survey site

\begin{tabular}{|c|c|}
\hline Location & $\begin{array}{l}\text { Percent } \\
\text { dead }\end{array}$ \\
\hline Austinmer, NSW & 0.0 \\
\hline Bagawa SF, NSW & 15.0 \\
\hline Bongil Bongil NP, NSW & 10.0 \\
\hline Brill Brill SF, NSW & 30.0 \\
\hline Brisbane Water NP, NSW & 0.0 \\
\hline Chichester SF, NSW & 8.3 \\
\hline Conglomerate SF, NSW & 0.0 \\
\hline Cunninghams Gap, QLD & 0.0 \\
\hline Ewingar SF 1, NSW & 0.0 \\
\hline Ewingar SF 2, NSW & 0.0 \\
\hline Flat Rock SF, NSW & 0.0 \\
\hline Gibraltar Range NP, NSW & 0.0 \\
\hline Gold Creek Reservoir, QLD & 73.3 \\
\hline Goongery, NSW & 15.4 \\
\hline Kiwarrak SF, NSW & 26.3 \\
\hline McDonald SF, NSW & 4.8 \\
\hline Mebbin NP 2, NSW & 0.0 \\
\hline Mebbin NP 4, NSW & 0.0 \\
\hline Middle Brother SF, NSW & 0.0 \\
\hline Morton NP, NSW & 0.0 \\
\hline Murramarang NP 1 , NSW & 4.5 \\
\hline Murramarang NP 2, NSW & 8.3 \\
\hline Murramarang NP 3, NSW & 16.7 \\
\hline Olney SF 1, NSW & 53.3 \\
\hline Olney SF 2, NSW & 0.0 \\
\hline Pine Creek SF, NSW & 0.0 \\
\hline Red Head, NSW & 40.0 \\
\hline Richmond Range NP, NSW & 0.0 \\
\hline Royal NP, NSW & 23.3 \\
\hline Seven Mile Beach NP, NSW & 16.7 \\
\hline Tallebudgera Valley 1, QLD & 25.0 \\
\hline Tallebudgera Valley 2, QLD & 0.0 \\
\hline Termeil SF 1, NSW & 0.0 \\
\hline Termeil SF 2, NSW & 0.0 \\
\hline Tomerong SF, NSW & 0.0 \\
\hline Tomerong, NSW & 0.0 \\
\hline Traveston Crossing 1, QLD & 0.0 \\
\hline Traveston Crossing 2, QLD & 13.3 \\
\hline Upper Burringbar, NSW & 0.0 \\
\hline Upper Sleepy Hollow, NSW & 0.0 \\
\hline Wambina NR, NSW & 11.1 \\
\hline Way Way SF, NSW & 0.0 \\
\hline Yabbra SF, NSW & 0.0 \\
\hline
\end{tabular}

$S F$ State Forest, NP National Park, NR Nature Reserve abundant endemic species. The damage to $R$. rubescens is just as extensive but less severe, with $12 \%$ of trees assessed as dead in our study, and tree mortality observed in fewer than half the stands. It appears, however, that $R$. rubescens can cope better with the disease because it can manage to produce some flush even after substantial defoliation. Still, based on our surveys, $R$. rubescens numbers have declined by over $10 \%$ in less than five years; this abundant species is also undergoing significant decline across its range.

Our quantitative findings for both species are supported by field botanists who have conducted extensive surveys of these species during routine botanical surveys and seed collecting over many years: “...all sites of $R$. rubescens visited since 2010 are in serious decline...with no flowering or seed observed" (Doug Beckers, Senior Botanist, National Parks and Wildlife Service, pers. comm., May 2014); " $R$. rubescens and $R$. psidioides are seriously threatened, with significant decline in all stands visited...the worst area in the Bellinger Valley [NSW] where hundreds of plants have died..." (Richard Johnstone, Seed Bank Officer/Botanist, The Australian Botanic Garden Mount Annan, pers. comm., July 2014); "Neither $R$. rubescens or $R$. psidioides have flowered since 2010, with at least half of $R$. rubescens dead and all known $R$. psidioides dead at monitoring sites" (Deb Holloman, Bush Regeneration Coordinator, National Parks and Wildlife Service, May 2015). Monitoring of $R$. rubescens and $R$. psidioides stands in northern NSW - which prior to 2011 appeared to be vigorous and in robust health-revealed devastating effects, with $75 \%$ tree mortality in some areas (Smith, M., National Parks and Wildlife Service, 2014, unpublished). The impact of $P$. psidii on these hitherto widespread species, neither of which is legislatively 'listed' under state or federal legislation, is likely to be sufficient to justify a change in their status to 'threatened' (IUCN 2001). While further investigations are required to determine the impacts on a range of host species, those considered threatened prior to $P$. psidii being detected in Australia and identified as being susceptible may be at greater risk of becoming extinct. Preliminary studies have already identified that the currently threatened species Rhodamnia angustifolia, a species with only 12 trees remaining in the wild, has been further threatened, with repeat infection resulting in loss of fecundity and rapid dieback (Pegg et al. 2014). 
Table 3 ANOVA table for fixed effects of field assessments of Rhodamnia rubescens

\begin{tabular}{lrrrr}
\hline Variables & Value & SE & t-value & $p$ value \\
\hline Intercept & 70.13 & 3.57 & 19.66 & $<0.001$ \\
Disease rating & 3.17 & 0.66 & 4.77 & $<0.001$ \\
Height (m) & -2.15 & 0.44 & -4.90 & $<0.001$ \\
Disease incidence on mature leaves & 0.20 & 0.03 & 6.04 & $<0.001$ \\
\hline
\end{tabular}

Table 4 Percentage of Rhodomyrtus psidioides trees assessed as dead at each survey site

\begin{tabular}{lr}
\hline Location & $\begin{array}{c}\text { Percent } \\
\text { dead }\end{array}$ \\
\hline Baggotville 1, NSW & 69.2 \\
Baggotville 2, NSW & 60.0 \\
Bongil Bongil NP, NSW & 72.5 \\
Broken Ridge, NSW & 100.0 \\
Cudgen NR, NSW & 0.0 \\
Ewingsdale, NSW & 100.0 \\
Goolawah RP, NSW & 24.0 \\
Myall Lakes NP, NSW & 23.1 \\
Port Macquarie 1, NSW & 11.8 \\
Port Macquarie 2, NSW & 0.0 \\
Red Head, NSW & 0.0 \\
Seal Rocks RP, NSW & 20.0 \\
Tallebudgera Valley, Qld & 96.7 \\
Tweed Coast, NSW & 15.0 \\
Upper Burringbar, NSW & 95.7 \\
Upper Sleepy Hollow, NSW & 12.5 \\
Wamberal Lagoon NR, NSW & 50.0 \\
Wambina NR, NSW & 33.3 \\
\hline NP National Pak, NR Nature Resre, RP Regionat & \\
\end{tabular}

$N P$ National Park, NR Nature Reserve, $R P$ Regional Park

The assessments of $R$. rubescens in Olney SF provided information not only on the effects of the disease on $R$. rubescens but on the progression of disease and rate of decline in the plant population. This revealed not only how quickly the tree crown declines (within 6 months) following repeated infection of immature leaves and subsequent defoliation, but also fluctuations in incidence and severity of disease over time. The study using the image processing software QUANT (Vale et al. 2003) provided more rigorous data on the effects of $P$. psidii on R. rubescens at Olney $\mathrm{SF}$. For the immature leaf class, we saw a significant difference in both disease severity and leaf area between treatments, indicating a causal relationship between disease and reduced leaf area. We had

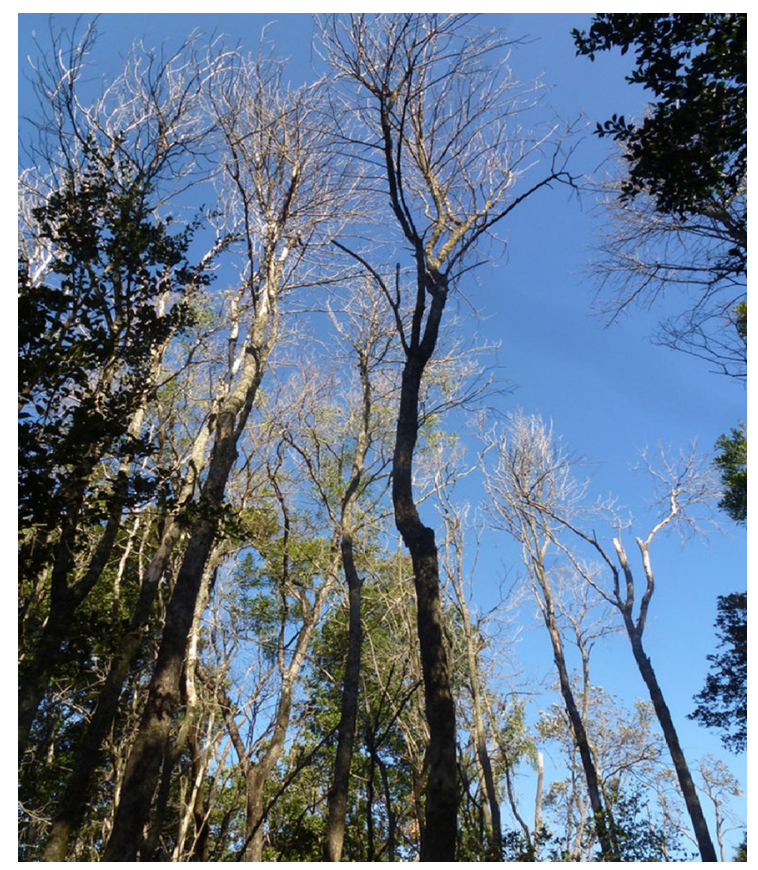

Fig. 6 Native stand of mature Rhodomyrtus psidioides in north coastal NSW where the majority of trees have been killed within 2-3 years of Puccinia psidii establishing. Photo P. Entwistle

hypothesized that reduced leaf size would be associated with increased crown transparency on trees: fewer leaves resulting in less photosynthesis leading to a gradual decline in carbohydrates for ongoing leaf production. However, we did not see a significant correlation between these traits. This may be an artifact of the trial design, as there were only three assessments (August, November, December 2011) of crown transparency prior to sampling leaves (February 2012). The data did, however, show that untreated trees had more disease, smaller leaves (when they did reach maturity) and higher crown transparency compared to treated trees. We surmise that the gradual decline in foliage retention on diseased trees resulted in a decrease in photosynthetic capability of these trees leading to a reduction in the size of newly produced 
leaves. Over time this likely resulted in the depletion of stored carbohydrates, affecting further leaf development and foliage replacement. Like $P$. dioica in Jamaica (MacLachlan 1938) and S. jambos in Hawai'i (Uchida and Loope 2009), $R$. rubescens and $R$. psidioides are severely defoliated by $P$. psidii, resulting in the production of highly susceptible new growth, which in-turn becomes severely infected and defoliated. Repeated defoliation leads to reduced foliage re-growth, affects reproduction, and ultimately causes tree morality, likely due to carbohydrate depletion (McPherson and Williams 1998).

The time-series observations of disease progression at Olney SF provide some corroboration of the published environmental factors that influence disease development. Periods of rainfall were generally followed by an increase in leaf production, even during winter. This abundant susceptible foliage, with continued high humidity and rainfall, provided ideal conditions for infection by $P$. psidii, and a subsequent increase in incidence and severity of disease generally within a month. Duration of leaf wetness and high relative humidity combined with nocturnal temperatures ranging from 18 to $22{ }^{\circ} \mathrm{C}$ have been recognized in previous studies as being triggers for disease outbreaks (Tessmann et al. 2001). The frequency and quantity of rainfall is also a likely factor of significance influencing rate and quantity of new leaf growth.

Our work showed that $P$. psidii has expanded across the entire natural range of our two study species, was found on every plant surveyed, and the damage to individual plants was generally high to extreme. The overall impact of an invasive species can be measured by the total area occupied (range), the abundance across that range, and the damage on individual plants (Parker et al. 1999). Thus, based on the metrics proposed by Parker et al. (1999), the impact of $P$. psidii on these two endemic species in natural ecosystems in Australia is severe. Our study, however, only investigated damage to individuals within populations, and as such more research is required to gain an understanding of the effects on plant communities and ecosystem processes (Parker et al. 1999). The short-term ecosystem-level impacts of $P$. psidii are likely to include a reduction in photosynthesis and productivity, stimulation of decomposition and changes in microclimate and light condition in the forest due to crown loss and mortality of highly susceptible species (Lovett et al. 2006). Longer term effects are likely to be related to a change in species composition, due to local extirpation of highly susceptible species, and subsequent changes of forest structure, productivity, and nutrient cycling. Already we are observing changes in plant community structure, with native grasses and exotic weeds (e.g. Lantana camara) colonizing gaps provided by mortality of $R$. psidioides stands (authors, pers. obs.).

Our selected species have proven useful in illustrating the potentially severe impact of $P$. psidii on other highly or extremely susceptible species in an ecologically critical family (Myrtaceae) that constitutes about $10 \%$ of the Australian flora by speciesabout half of which occur in climatic zones identified as conducive to $P$. psidii naturalisation (Kriticos et al. 2013). Pegg et al. (2014) considered 48 species in Queensland alone to be highly or extremely susceptible to $P$. psidii. We recommend a greater range of species with a broader variation in susceptibility be monitored, including both currently 'listed' threatened species and 'non-listed' species. Understanding the variability in species susceptibility is critical in order to optimize scarce resources for potential species recovery plans. Such monitoring will also assist in detecting changes in disease severity due to local and regional variation in climate and potentially herald the incursion of new strains of P. psidii (e.g. Loope 2010). The introduction of new strains of $P$. psidii into Jamaica (MacLachlan 1938) and Florida (Rayachhetry et al. 1997) resulted in devastating epidemics not previously seen in those counties. Furthermore, it is imperative that monitoring of plant communities and ecosystems are initiated to fully understand the longterm impact of this devastating invasive pathogen.

In just the short time that $P$. psidii has been established in Australian natural ecosystems we have observed significant damage and tree mortality. There are few exotic diseases in Australia that threaten a wide range of Australian flora. The most significant of these is Phytophthora cinnamomi, which is associated with mortality of a wide range of overstorey and understorey species in multiple families including Myrtaceae, Proteaceae, Epacridaceae and Papilionaceae (Wills 1992; Weste 1994). Phytophthora cinnamomi is associated with significant ecological impact in plant communities in south-eastern and south-western Australia, with declines in species richness, plant abundance and percentage cover 
(Wills 1992; Weste 1994). Fauna dependent on these plant communities are also affected. While $P$. psidiiassociated mortality of dominant overstorey trees has not yet been recorded (although effects on vegetative and seedling recruitment of these remain unknown), over time we are likely to see significant alterations to understorey plant communities due to $P$. psidii.

There are numerous examples of invasive forest pathogens causing landscape-level ecological impacts (Ellison et al. 2005; Loo 2009), including chestnut blight (Cryphonectria parasitica) in North America (Anagnostakis 1987), Dutch elm disease (Ophiostoma ulmi and O. nova-ulmi) in Europe and North America (Gibbs 1978) and phytophthora dieback (Phytophthora cinnamomi) in Australia (Wills 1992; Weste 1994). The greatest impacts occur when invasive pathogens cause mortality of foundation species (Ellison et al. 2005; Loo 2009). Death of foundation species are also often very dramatic, garnering government and public attention, e.g. phytophthora dieback, Dutch elm disease and chestnut blight. Although receiving government and public attention prior to reaching Australia (e.g., O’Neill 2000; Grgurinovic et al. 2006), and during the emergency response following detection (e.g., Carnegie and Cooper 2011; Makinson 2012), interest in P. psidii in Australia has waned, partly because the "mycological firestorm" that "environmentalists predicted" does not appear to have eventuated (according to McRae 2013); there has been no large scale tree mortality and minimal affects to industries so far. Our studies, while currently limited, have shown that $P$. psidii is severely affecting key species in natural ecosystems, and likely to be significantly affecting a wider range of species. Local extirpation of highly susceptible species is likely, potentially leading to species extinction. This work clearly illustrates the potential for $P$. psidii to negatively affect Australia's biodiversity.

Acknowledgments We thank Chris Slade, Dave Power, Kelly Rowley (Forestry Corporation of NSW), Martin Smith, Phil Craven, Deb Holloman (National Parks and Wildlife Service) for assistance with identifying sites to assess. Kris Kupsch (Ecoflora) assisted with assessment of sites in northern NSW. Forestry Corporation of NSW and Office of Environment and Heritage are thanked for allowing access to State Forests and National Parks, respectively. Matt Mo assisted with the QUANT analysis. The Plant Biosecurity Cooperative Research Centre provided financial support. The authors would like to acknowledge the support of the Australian Government's Cooperative Research Centers Program. AC also thanks
Forestry Corporation of NSW for support. Bob Makinson, Louise Morin, Michelle Leishman and two anonymous reviewers provided helpful suggestions on earlier drafts of the manuscript.

Open Access This article is distributed under the terms of the Creative Commons Attribution 4.0 International License (http:// creativecommons.org/licenses/by/4.0/), which permits unrestricted use, distribution, and reproduction in any medium, provided you give appropriate credit to the original author(s) and the source, provide a link to the Creative Commons license, and indicate if changes were made.

\section{References}

Anagnostakis SL (1987) Chestnut blight: the classical problem of an introduced pathogen. Mycologia 79:23-37

Carnegie AJ (2015) First report of Puccinia psidii (myrtle rust) in Eucalyptus plantations in Australia. Plant Dis 99:161

Carnegie AJ, Cooper KC (2011) Emergency response to the incursion of an exotic myrtaceous rust in Australia. Australas Plant Pathol 40:346-359

Carnegie AJ, Lidbetter JR (2012) Rapidly expanding host range of Puccinia psidii sensu lato in Australia. Australas Plant Pathol 41:13-29

Carnegie AJ, Lidbetter JR, Walker J, Horwood MA, Tesoriero L, Glen M, Priest MJ (2010) Uredo rangelii, a taxon in the guava rust complex, newly recorded on Myrtaceae in Australia. Australas Plant Pathol 39:463-466

Chatfield C (2003) The analysis of time series: an introduction, 6th edn. Chapman \& Hall, London

Commonwealth Department of Primary Industry (1985) Guava rust: Puccinia psidii Winter. Plant Quarantine Leaflet No. 45

Coutinho TA, Wingfield MJ, Alfenas AC, Crous PW (1998) Eucalyptus rust: a disease with the potential for serious international implications. Plant Dis 82:819-825

Dale WT (1955) A preliminary list of Jamaican Uredinales. Mycol Pap 60:1-22

Diggle PJ (1990) Time series: a biostatistical introduction. Clarendon Press, Oxford

Ellison AM, Bank MS, Clinton BD, Colburn EA, Elliot K, Ford CR, Foster DR, Kloeppel BD, Knoepp JD, Lovett GM, Mohan J, Orwig DA, Rodenhouse NL, Sobczak WV, Stinson KA, Stone JK, Swan CM, Thompson J, Von Holle B, Webster JR (2005) Loss of foundation species: consequences for the structure and dynamics of forested ecosystems. Front Ecol Environ 3:479-486

Ferrari JT, Noguira EMC, dos Santos AJT (1997) Control of rust (Puccinia psidii) in guava (Psidium guajava). Acta Hortic 452:55-57

Ferreira FA (1983) Ferrugem do eucalipto. Rev Arvore 7:91-109

Floyd AG (1989) Rainforest trees of mainland south-eastern Australia. Forestry Commission of NSW, Inkata Press, Sydney

Gibbs JN (1978) Intercontinental epidemiology of Dutch elm disease. Ann Rev Phytopath 16:287-307 
Giblin F (2013) Myrtle rust report: new Caledonia. University of the Sunshine Coast, Maroochydore

Giblin F, Carnegie AJ (2014) Puccinia psidii (myrtle rust)— global host list. https://www.anbg.gov.au/anpc/resources/ Myrtle_Rust.html. Accessed on October 2014

Glen M, Alfenas AC, Zauza EAV, Wingfield MJ, Mohammed C (2007) Puccinia psidii: a threat to the Australian environment and economy-a review. Australas Plant Pathol 36:1-16

Grgurinovic CA, Walsh D, Macbeth F (2006) Eucalyptus rust caused by Pucinia psidii and the threat it poses to Australia. EPPO Bull 36:486-489

International Union for Conservation of Nature (2001) IUCN Red List categories and criteria: version 3.1. IUCN Species Survival Commission. IUCN, Gland, Switzerland and Cambridge, UK. http://jr.iucnredlist.org/documents/redlist_ cats_crit_en.pdf

Kawanishi T, Uemastu S, Kakishima M, Kagiwada S, Hamamoto H, Horie H, Namba S (2009) First report of rust disease on ohia and the causal fungus in Japan. J Genetic Plant Path 75:428-431

Kriticos DJ, Morin L, Leriche A, Anderson RC, Caley P (2013) Combining a climatic niche model of an invasive fungus with its host species distributions to identify risks to natural assets: Puccinia psidii sensu lato in Australia. PLoS One 8(5):e64479

Lim T-K, Manicom BQ (2003) Diseases of guava. Diseases of tropical fruit crops. CAB International, Wallingford, pp 275-289

Loo AL (2009) Ecological impacts of non-indigenous invasive fungi as forest pathogens. Biol Inv 11:81-96

Loope L (2010) A summary of information on the rust Puccinia psidii Winter (guava rust) with emphasis on means to prevent introduction of additional strains to Hawaii. U.S. Geological Survey Open File Report 2010-1002. U.S. Geological Survey, Reston

Lovett GM, Canham CD, Arthur MA, Weathers KC, Fitzhugh RD (2006) Forest ecosystem responses to exotic pests and pathogens in eastern North America. Bioscience 56:395405

Machado PDS, Alfenas AC, Alfenas RF, Mohammed CJ, Glen M (2015) Microsatellite analysis indicates that Puccinia psidii in Australia is mutating but not recombining. Australas Plant Pathol 44:455-462

MacLachlan JD (1938) A rust of the pimento tree in Jamaica, B.W.I. Phytopathology 28:157-170

Makinson RO (2012) Myrtle rust-a major new threat for Australian biodiversity. Bush Matters 14: 10-11. http:// www.environment.nsw.gov.au/

Makinson RO (2014) Myrtle rust-what's happening? Aust Plant Conserv 23:13-15

Marlatt RB, Kimbrough JW (1980) Rust (Puccinia psidii) of allspice (Pimenta dioica) appears in Florida. In: Proceedings of the Florida state horticultural society, vol 93, p 111

McPherson K, Williams K (1998) The role of carbohydrate reserves in growth, resilience, and persistence of cabbage palm sedlings (Sabal palmetto). Oecologia 117:460-468

McRae M (2013) Whatever happened to myrtle rust? Ecos Issue 184, 21 June 2013. http://www.ecosmagazine.com

Morin L, Aveyard R, Lidbetter JR, Wilson PG (2012) Investigating the host-range of the rust fungus Puccinia psidii sensu lato across tribes of the family Myrtaceae present in Australia. PLoS One 7(4):e35434

Myerscough PJ (1998) Ecology of Myrtaceae with special reference to the Sydney Region. Cunninghamia 5:787-807

O’Neill G (2000) Resistance is useless. Bulletin 28:44-45

Parker IM, Simberloff D, Lonsdale WM, Goodell K, Wonham M, Kareiva PM, Williamson MH, Von Holle B, Moyle PB, Byers JE, Goldwasser L (1999) Impact: towards a framework for understanding the ecological effects of invaders. Biol Inv 1:3-19

Pegg GS, Perry S, Carnegie AJ, Ireland K, Giblin F (2012) Understanding myrtle rust epidemiology and host specificity to determine disease impact in Australia. Cooperative Research Centre for National Plant Biosecurity Report CRC70186. http://legacy.crcplantbiosecurity.com.au/pub lications/npb1893.html

Pegg GS, Giblin FR, McTaggart AR, Guymer GP, Taylor H, Ireland KB, Shivas RG, Perry S (2014) Puccinia psidii in Queensland, Australia: disease symptoms, distribution and impact. Plant Pathol 63:1005-1021

Pinheiro JC, Bates DM (2000) Mixed-effects models in S and S-Plus. Springer, New York

Pinheiro J, Bates D, DebRoy S, Sarkar D and R Core Team (2014) nlme: linear and nonlinear mixed effects models. R package version 3, pp 1-117. http://CRAN.Rproject.org/ package $=$ nlme

R Development Core Team (2014) R: a language and environment for statistical computing. R Foundation for Statistical Computing, Vienna

Rayachhetry MB, Elliot ML, Van TK (1997) Natural epiphytotic of a rust fungus (Puccinia psidii) on Melaleuca quinquenervia in Florida. Plant Dis 81:831

Rayamajhi MB, Pratt PD, Klopfenstein NB, Ross-Davis AL, Rogers L (2013) First report of Puccinia psidii caused rust disease epiphytotic on the invasive shrub Rhodomyrtus tomentosa in Florida. Plant Dis 97:1379

Roux J, Greyling I, Coutinho TA, Verleur M, Wingfield MJ (2013) The Myrtle rust pathogen, Puccinia psidii, discovered in Africa. IMA Fungus 4:155-159

Sarkar D (2008) Lattice: multivariate data visualization with R. Springer, New York

Schomaker ME, Zarnoch SJ, Bechtold WA, Latelle DJ, Burkman WG, Cox SM (2007) Crown-condition classification: a guide to data collection and analysis. General Technical Report SRS-102. U.S. Department of Agriculture, Forest Service, Southern Research Station, Asheville

Shaw S (2015) Focus on Flora: Rhodomyrtus psidioides, Native Guava. Sunshine Coast Bush Hands, Sumer 2015, p 3. http://www.sunshinecoast.qld.gov.au/sitePage.cfm?code= bush-hands

Tessmann DJ, Dianese JC, Miranda AC, Castro LHR (2001) Epidemiology of a neotropical rust (Puccinia psidii): periodical analysis of the temporal progress in a perennial host (Syzygium jambos). Plant Pathol 50:725-731

Uchida JY, Loope LL (2009) A recurrent epiphytotic of guava rust on rose apple, Syzygium jambos, in Hawaii. Plant Dis 93:429

Uchida J, Zhong S, Kilgore E (2006) First report of a rust disease on 'ohia caused by Puccinia psidii in Hawaii. Plant Dis 90:524

Vale FXR, Fernandes Filho EI, Liberato JR (2003) QUANT. A software for plant disease severity assessment. In: 
Proceedings of the 8th international congress of plant pathology, Christchurch, New Zealand, p 105

Walker J (1983) Pacific mycogeography: deficiencies and irregularities in the distribution of plant parasitic fungi. Aust J Bot (Suppl Ser) 10:89-136

Weste G (1994) Impact of Phytophthora species on native vegetation of Australia and Papua New Guinea. Australas Plant Pathol 23:190-209

Wickham H (2009) ggplot2: elegant graphics for data analysis. Springer, New York

Williams G, Adam P (2010) The flowering of Australia's rainforests: a plant and pollination miscellany. CSIRO Publishing, Clayton
Wills RT (1992) The ecological impact of Phytophthora cinnamomi in the Stirling Range National Park, Western Australia. Aust J Ecol 17:145-159

Winter G (1884) Repertorium. Rabenhorstii fungi europaei et extraeuropaei exsiccati cura Dr. G. Winter. Centuria XXXI et XXXII. Hedwigia 23:164-172

Zhuang J-Y, Wei S-X (2011) Additional materials for the rust flora of Hainan Province, China. Mycosystema 30:853860

Zuur AF, Ieno EN, Walker N, Saveliev AA, Smith GM (2009) Mixed effects models and extensions in ecology with R. Springer, New York 